\title{
Renal and Cardiovascular Effects of Atrial Natriuretic Peptide in Fetal Sheep
}

\author{
BARBARA Y. HARGRAVE, HARRIET S. IWAMOTO, AND ABRAHAM M. RUDOLPH \\ Cardiovascular Research Institute and the Departments of Physiology, Pediatrics and Obstetrics, Gynecology and \\ Reproductive Sciences, University of California, San Francisco, California 94143
}

\begin{abstract}
In the adult, atrial natriuretic peptide (ANP) has been postulated to regulate renal and cardiovascular function both when blood volume is expanded and when atrial pressure is increased. In late gestation fetal sheep, ANP has been detected in plasma concentrations higher than in pregnant adults; however, its function in the fetus is unclear. To assess the role of ANP in mediating changes in combined ventricular output and organ blood flow, GFR, urine flow rate, and urinary sodium excretion, we studied 11 chronically cannulated fetal sheep at 126 to $131 \mathrm{~d}$ gestation (term $145 \mathrm{~d}$ ). We infused ANP in doses of $27 \pm$ 4 and $55 \pm 8 \mathrm{ng} / \mathrm{kg} / \mathrm{min}$ into nine of the 11 fetuses and vehicle only into the remaining two fetuses. ANP increased hematocrit, $\mathrm{Hb}$, and plasma protein concentrations, which suggests that blood volume decreased. Combined ventricular output and umbilical-placental blood flow, measured by the radionuclide-labeled microsphere technique, decreased from $458 \pm 158$ to $344 \pm 59 \mathrm{ml} / \mathrm{min} / \mathrm{kg}$ and 210 \pm 85 to $144 \pm 31 \mathrm{ml} / \mathrm{min} / \mathrm{kg}$, respectively and the calculated umbilical-placental vascular resistance increased from $0.20 \pm 0.10$ to $0.32 \pm 0.09 \mathrm{~mm} \mathrm{Hg} / \mathrm{ml} / \mathrm{min} / \mathrm{kg}$ during the infusion of the high ANP dose. Blood flow to the gastrointestinal tract decreased with the high dose of ANP but blood flow to all other organs, mean arterial blood pressure, and heart rate did not change significantly. The effects of ANP on fetal renal function were minimal. Thus, ANP may play a role in maintaining fluid homeostasis in the fetus through its ability to decrease blood volume and to decrease combined ventricular output and umbilicalplacental blood flow. (Pediatr Res 26: 1-5, 1989)
\end{abstract}

\section{Abbreviations}

ANP, atrial natriuretic peptide

i.d., inner diameter

o.d., outer diameter

ANP is a peptide hormone located in the cardiac atria of many adult mammalian species. Plasma concentrations of ANP increase when extracellular fluid volume is expanded or when atrial pressure is increased (1). Increased plasma concentrations of ANP have a variety of renal, cardiovascular, and endocrine effects (2). Large doses of ANP cause diuresis and natriuresis (2), a decrease in arterial blood pressure and cardiac output (3), inhibition of renin secretion after a decrease in renal perfusion pressure (4), and inhibition of aldosterone and vasopressin secre-

Received November 7, 1988; accepted March 1, 1989

Correspondence Dr. Barbara Hargrave, Box 0544. HSE 1403, Cardiovascular Research Institute, University of California San Francisco, 513 Parnassus Ave., San Francisco. CA 94143.

Supported by NIH Grant HD17618. tion in vitro (2). However, recent studies have suggested that smaller physiologic doses of ANP may have minimal effects on these variables under basal conditions $(5,6)$.

ANP is present in the fetal cardiac atria and ventricles (7). Basal plasma concentrations of ANP are greater in the fetus than in the pregnant adult and increase further after volume expansion and acute hypoxemia $(8,9)$. At present, relatively little is known about the effects of ANP in the fetus. Injection of large amounts of ANP $(8 \mu \mathrm{g} / \mathrm{kg})$ decreases arterial blood pressure and increases heart rate (10). However, infusion of smaller amounts of ANP (70 $\mathrm{ng} / \mathrm{min})$ increases renal excretion of sodium, potassium, and calcium, but does not change heart rate or mean arterial blood pressure (11). Unfortunately, the plasma concentrations at which these effects occurred were not available. However, a study by Robillard et al. (12) showed that infusion of ANP at $100 \mathrm{ng} / \mathrm{kg} /$ min decreases renal blood flow velocity and increases renal vascular resistance. They also observed an increase in the urinary excretion of chloride and sodium; they did not, however, observe significant changes in urine flow or GFR. To more closely examine the relationship between plasma ANP concentrations and cardiovascular and renal responses in the fetus, we infused ANP into fetal sheep and measured combined ventricular output, organ blood flow, GFR, and urinary excretion of sodium.

\section{MATERIALS AND METHODS}

Surgical procedures. Pregnant ewes were fasted for 24-36 h before surgery. Epidural or spinal anesthesia was induced by injecting $4 \mathrm{ml}$ tetracaine $\mathrm{HCl}$ (Pontocaine $\mathrm{HCl}$, Breon Laboratories, New York, NY). A local anesthetic $(0.25 \%$ lidocaine hydrochloride) was injected subcutaneously before each maternal and fetal skin incision. Polyvinyl catheters $(1.3 \mathrm{~mm}$ i.d., $2.3 \mathrm{~mm}$ o.d.) were placed in the left pedal artery and vein of the ewe and advanced to the descending aorta and inferior vena cava, respectively. A total of $10 \%$ dextrose in $0.9 \% \mathrm{NaCl}$ solution was infused continuously into the ewe, and ketamine was given intravenously in 50-100 mg amounts every $15-20 \mathrm{~min}$.

The uterus was exposed through a midline incision in the abdomen of the ewe. An incision $(2.5 \mathrm{~cm})$ was made in the uterus to expose the fetal hind limbs. Polyvinyl catheters $(0.8$ $\mathrm{mm}$ i.d., $1.2 \mathrm{~mm}$ o.d.) were placed in a pedal vein and artery and advanced to the inferior vena cava (for intravenous infusions of ANP and tritiated inulin and for injection of radionuclidelabeled microspheres) and to the descending aorta (for measurement of arterial blood pressure and withdrawal of blood samples), respectively. A catheter ( $1.3 \mathrm{~mm}$ i.d., $2.3 \mathrm{~mm}$ o.d.) was also placed in the amniotic fluid cavity for measurement of amniotic fluid pressure.

In six fetuses the bladder was exposed through a midline incision in the fetal abdomen, and we inserted an additional catheter (no. $8 \mathrm{~F}$ polyvinyl tube) into the bladder through a purse-string suture. The fetal hind limbs were returned to the uterus, and the uterine incision was sutured. 
A second uterine incision was made to expose the fetal neck. Polyvinyl catheters $(0.8 \mathrm{~mm}$ i.d., $1.2 \mathrm{~mm}$ o.d.) were inserted into the carotid artery and jugular vein and advanced to the ascending aorta for withdrawal of reference samples and to the superior vena cava for injection of radionuclide-labeled microspheres.

All incisions were sutured, and all catheters were exteriorized at the maternal flank and placed in a cloth pouch for protection. To maintain a continuous flow of urine, the bladder and amniotic catheters were connected. At the end of surgery and daily thereafter, antibiotics were placed in the amniotic sac and given intravenously to the ewe $(100 \mathrm{mg}$ gentamicin and 1 million $U$ penicillin G). Antibiotics were not given on the day of the experiment. All animals were allowed at least $5 \mathrm{~d}$ to recover from surgery before any experiments were performed. All ewes were housed in individual cages and allowed free access to food and water.

Experimental protocol. We studied 11 chronically cannulated fetuses at gestational ages of 126-131 d (term $=145 \mathrm{~d}$ ). We infused ANP into nine of these fetuses. Six of the nine fetuses had catheters placed into their bladders. Two of these six received vehicle infusions only and served as controls.

On the day of the experiment, the ewe was placed in a mobile cart, brought to the laboratory, and allowed at least $2 \mathrm{~h}$ to acclimate to its surroundings. The catheters were opened and filled with fresh heparin-saline solution. The bladder catheter was disconnected from the amniotic catheter and allowed to drain for at least $\mathrm{Ih}$ to allow complete emptying of the bladder. Fetal arterial pressure, amniotic pressure, and heart rate were monitored throughout the experiments with Statham P23Db strain gauge transducers (Gould Inc., Oxnard CA), and recorded continuously on a Gould 2899s recorder (Gould Inc., Santa Clara, CA). Fetal heart rate was measured by a cardiotachometer triggered by an arterial pulse wave. All fetal arterial pressures were corrected to amniotic fluid pressure as zero reference. To determine the glomerular filtration rate, tritiated inulin $(0.33$ $\mu \mathrm{Ci} / \mathrm{g}$, New England Nuclear, Boston, MA) was dissolved in 5\% dextrose containing $0.2 \% \mathrm{NaCl}$ and infused intravenously at $0.033 \mu \mathrm{Ci} / \mathrm{min}(0.1 \mathrm{ml} / \mathrm{min})$ into the fetus, beginning $1 \mathrm{~h}$ before the start of the experiment and continuously thereafter.

The 280 min experiment was divided into a 60 -min equilibration period, a 60-min control period, and two 80-min ANP infusion periods. During each infusion, 20 min were allowed for ANP concentrations to come to steady state (hANP 1-28, Peninsula Laboratories, Belmont, CA, $0.1 \mathrm{ml} / \mathrm{min}$ ). ANP was infused at either 83 or $166 \mathrm{ng} / \mathrm{min}$. Fetal weights ranged from 2.4 to $3.8 \mathrm{~kg}(3.1 \pm 0.49 \mathrm{~kg}$, mean $\pm \mathrm{SD})$. Corrected for body wt, the infused doses of ANP were $27 \pm 4$ and $55 \pm 8 \mathrm{ng} / \mathrm{kg} / \mathrm{min}$ The order of dose administration was randomized. In two of the 11 fetuses, $5 \%$ dextrose containing $0.2 \% \mathrm{NaCl}$ was infused at 0.1 $\mathrm{ml} / \mathrm{min}$.

During the control and infusion periods, three 20-min urine collections were made and three blood samples were collected (3 $\mathrm{ml}$ ). Blood samples were collected in heparinized syringes, placed in tubes containing EDTA $(6 \mathrm{mg}$ ) and aprotinin (Trasylol 150 $\mathrm{KIU} / \mathrm{ml}$ ), and immediately placed on ice. The plasma was separated and stored frozen at $-70^{\circ} \mathrm{C}$ until extraction.

At the end of the control and infusion periods, radionuclidelabeled microspheres were injected for determination of combined ventricular output and regional blood flows as described previously (13). Briefly, microspheres labeled with ${ }^{153} \mathrm{Gd},{ }^{57} \mathrm{Co}$, ${ }^{114} \mathrm{In},{ }^{51} \mathrm{Cr},{ }^{113} \mathrm{Sn},{ }^{85} \mathrm{Sr},{ }^{95} \mathrm{Nb},{ }^{54} \mathrm{Mn}$, or ${ }^{65} \mathrm{Zn}$ were injected into the inferior and superior vena cavae of the fetus whereas blood was withdrawn from the descending and ascending aortic catheters at a rate of $3.88 \mathrm{ml} / \mathrm{min}$ (reference samples). The reference samples were collected starting $10 \mathrm{~s}$ before the microsphere injection was begun and ending $45 \mathrm{~s}$ after the injection was completed. Blood removed for reference samples and for chemical analysis was replaced with an equal volume of fetal or maternal blood at the time of sampling. At the end of the study the ewe and fetus were killed with an intravenous injection of sodium pentobarbital, and the fetus was dissected. To calculate individual organ blood flows, organs were incinerated and radioactivity counted in a multichannel pulse analyzer. Blood flow to the upper body organs was calculated as flow organ $=\mathrm{cpm}$ in organ/cpm in carotid artery $(\mathrm{Ca})$ reference sample $\times$ flow $_{\mathrm{Ca}}$ reference sample. Blood flow to the lower body organs was calculated as flow organ $=\mathrm{cpm}$ in organ $/ \mathrm{cpm}$ in femoral artery $(\mathrm{Fa})$ reference sample $\times$ flow $_{\mathrm{Fa}}$ reference.

Assays. Plasma atrial natriuretic peptide concentrations were measured by RIA using a kit (Alpha ANP [ ${ }^{125}$ I] RIA System, Amersham, Arlington Heights, IL). All plasma samples were extracted on $\mathrm{C}_{18}$ columns (Sep Pac, Waters Associates, Milford, MA). Each column was washed with methanol and distilled water. Plasma samples $(1 \mathrm{ml})$ were added to the column and eluted with methanol/trifluoroacetic acid. The eluates were dried under nitrogen and reconstituted with assay buffer $(500 \mu \mathrm{l})$. Duplicate $100 \mu \mathrm{l}$ plasma extract or standard was then assayed. Because all plasma samples were extracted, an extracted standard curve was also prepared using charcoal-treated plasma. The two standard curves were parallel, and intra-assay and inter-assay coefficients of variation were 13 and $22 \%$, respectively $(n=6)$.

Fetal and maternal arterial blood $\mathrm{pH}, \mathrm{PCO}_{2}$, and $\mathrm{PO}_{2}$ were determined on a Corning 158 Blood Gas Analyzer (Corning Medical, Medfield, MA). Blood $\mathrm{Hb}$ concentration and arterial blood oxygen saturation were measured on a Radiometer hemoximeter (OSM2, Copenhagen, Denmark). Hematocrit was measured using the microcapillary technique, and plasma protein concentrations were determined by refractometry. Fetal urinary and plasma concentrations of sodium and potassium were measured on a flame-photometer (IL343, Instrumentation Laboratories, Lexington, MA).

Data analysis. Responses of the measured variables to atrial natriuretic peptide administration were analyzed by one-way analysis of variance corrected for repeated measures. A Dunnett's $t$ test was used to determine which means were statistically different from control values. Fetal blood pressure and heart rate values were obtained by averaging 12 points every 5 min during the last $60 \mathrm{~min}$ of the control and infusion periods. Means were considered to be significantly different if $p<0.05$. All data are reported as mean $\pm \mathrm{SD}$.

To calculate urine flow rate, urine was collected in a preweighed sample tube. The initial wt of the tube was subtracted from the final wt, and the difference divided by the collection time. To calculate GFR, we divided the urinary concentration of inulin times the urine volume by the plasma concentration of inulin. The excretion rate of sodium was calculated by multiplying the urinary concentration of sodium by the urine volume.

\section{RESULTS}

Fetal blood gases and $\mathrm{pH}$ were within normal levels and did not change during ANP infusion (Table 1). Fetal plasma ANP concentrations increased from control values of $247 \pm 159$ to $429 \pm 357 \mathrm{pg} / \mathrm{ml}$ during the low-dose infusion of ANP $(p<$ 0.05 ) and increased further to $984 \pm 429 \mathrm{pg} / \mathrm{ml}$ during the highdose infusion of ANP $(p<0.05)$ (Table 1$)$. Maternal plasma AMP concentrations did not change significantly from control values of $74 \pm 38 \mathrm{pg} / \mathrm{ml}$ during fetal infusion of ANP and were lower than basal ANP concentrations in the fetus.

With the low-dose infusion, ANP produced minimal effects on the hemodynamic variables we measured. When plasma ANP concentrations were increased further, we observed a $29 \%$ decrease in combined ventricular output and a $31 \%$ decrease in umbilical-placental blood flow (Table 2). In addition, calculated umbilical-placental vascular resistance increased during the highdose ANP infusion (Table 2). However, fetal body blood flow (combined ventricular output minus umbilical-placental blood flow) (Table 2), mean arterial pressure, and heart rate (Table 1) did not change significantly. Blood flow to the gastrointestinal tract decreased significantly with the high-dose infusion of ANP; 
Table 1. Effect of atrial natriuretic peptide infusion on blood composition and cardiovascular function in fetal lamb (mean $\pm S D)$

\begin{tabular}{lccc}
\hline & Control & $\begin{array}{c}\text { Low ANP } \\
\text { dose }\end{array}$ & $\begin{array}{c}\text { High ANP } \\
\text { dose }\end{array}$ \\
\hline $\mathrm{pH}$ & $7.35 \pm 0.03$ & $7.34 \pm 0.03$ & $7.34 \pm 0.03$ \\
$\mathrm{PCO}_{2}(\mathrm{~mm} \mathrm{Hg})$ & $53 \pm 5$ & $52 \pm 5$ & $52 \pm 5$ \\
$\mathrm{PO}_{2}(\mathrm{~mm} \mathrm{Hg})$ & $19 \pm 3$ & $20 \pm 4$ & $21 \pm 4$ \\
$\begin{array}{l}\text { Fetal plasma ANP } \\
\quad(\mathrm{pg} / \mathrm{l})\end{array}$ & $247 \pm 159$ & $429 \pm 357^{*}$ & $984 \pm 429^{*}$ \\
$\begin{array}{l}\text { Fetal Hb (g/dl) } \\
\begin{array}{l}\text { Mean arterial pressure } \\
(\mathrm{mm} \mathrm{Hg})\end{array}\end{array}$ & $9.1 \pm 1.9$ & $9.5 \pm 2$ & $9.5 \pm 1.9^{*}$ \\
$\begin{array}{l}\text { Heart rate (beats/min) } \\
\text { ratm }\end{array}$ & $190 \pm 22$ & $188 \pm 25$ & $186 \pm 20$ \\
\hline
\end{tabular}

$* p<0.05 ; n=9$.

Table 2. Effect of atrial natriuretic peptide infusion on cardiovascular function in the fetal lamb (mean $\pm S D)^{*}$

\begin{tabular}{lccc}
\hline & Control & $\begin{array}{c}\text { Low ANP } \\
\text { dose }\end{array}$ & $\begin{array}{c}\text { High ANP } \\
\text { dose }\end{array}$ \\
\hline $\begin{array}{l}\text { Combined ventricular out- } \\
\text { put }(\mathrm{ml} / \mathrm{min} / \mathrm{kg} \text { ) }\end{array}$ & $458 \pm 158$ & $427 \pm 161$ & $344 \pm 59^{*}$ \\
$\begin{array}{l}\text { Fetal body blood flow (ml/ } \\
\text { min } / \mathrm{kg})\end{array}$ & $248 \pm 73$ & $237 \pm 121$ & $200 \pm 28$ \\
$\begin{array}{l}\text { Umbilical-placental blood } \\
\quad \text { low }(\mathrm{ml} / \mathrm{min} / \mathrm{kg})\end{array}$ & $210 \pm 85$ & $190 \pm 40$ & $144 \pm 31^{*}$ \\
$\begin{array}{l}\text { Umbilical-placental vascu- } \\
\text { lar resistance }(\mathrm{mm} \mathrm{Hg} / \\
\mathrm{ml} / \mathrm{min} / \mathrm{kg})\end{array}$ & $0.20 \pm 0.10$ & $0.29 \pm 0.16$ & $0.32 \pm 0.09^{*}$ \\
\hline
\end{tabular}

* Resistances were calculated as the quotient of the arteriovenous pressure difference and blood flow.

$\dagger p<0.05 ; n=9$.

in general, blood flows decreased and vascular resistances increased in all other organs, but these changes were not statistically significant (Table 3 ).

Figure 1 shows individual results for hematocrit and plasma protein concentrations. Hematocrit increased from $30 \pm 6$ to 31 $\pm 5 \%(p<0.01)$ and $\mathrm{Hb}$ concentration increased from $9.0 \pm 2.0$ to $9.5 \pm 1.9 \mathrm{~g} / \mathrm{dl}(p<0.001)$ (Fig. 1). The fetal plasma protein concentration increased from $3.6 \pm 0.5$ to $3.8 \pm 0.3$ during the low-dose ANP infusions $(p<0.01)$ and to $3.9 \pm 0.4 \mathrm{~g} / \mathrm{dl}(p<$ $0.007)$ after the high-dose ANP infusions (Fig. 1). Collectively, these data suggest that ANP decreased blood volume by approximately $5 \%$.

GFR increased slightly with the ANP infusions, but this change was not significant. The amount of sodium filtered also increased slightly as did sodium excretion, but these changes also were not significant. Urine flow rate and fractional excretion of sodium were unchanged by ANP.

No significant changes were observed in combined ventricular output, umbilical placental blood flow, hematocrit, $\mathrm{Hb}$ and protein concentrations, GFR, or urinary sodium excretion in the fetuses receiving the vehicle infusion.

\section{DISCUSSION}

The doses of ANP used in this study were chosen to increase fetal plasma ANP concentrations within a physiologic range. Previous studies have shown that volume expansion of fetuses with isotonic saline increases plasma ANP concentrations from $115 \pm 24$ to $409 \pm 72 \mathrm{pg} / \mathrm{ml}$ (9). Similarly, when fetuses were made severely hypoxemic, plasma ANP concentrations increased
Table 3. Effect of ANP infusion on organ blood flows and calculated resistances in fetal lambs*

\begin{tabular}{lccc}
\hline & Control & Low ANP dose & High ANP \\
\hline Adrenals & & & \\
Flow & $218 \pm 47$ & $207 \pm 131$ & $197 \pm 61$ \\
Resistance & $0.19 \pm 0.08$ & $0.27 \pm 0.17$ & $0.24 \pm 0.11$ \\
\% CVO & $0.06 \pm 0.02$ & $0.06 \pm 0.02$ & $0.08 \pm 0.02 \dagger$ \\
Spleen & & & \\
Flow & $367 \pm 187$ & $336 \pm 174$ & $232 \pm 131$ \\
Resistance & $0.19 \pm 0.2$ & $0.13 \pm 0.07$ & $0.27 \pm 0.08$ \\
\% CVO & $1.4 \pm 0.9$ & $1.5 \pm 1.0$ & $1.2 \pm 0.7$ \\
Kidneys & & & \\
Flow & $184 \pm 57$ & $177 \pm 44$ & $168 \pm 26$ \\
Resistance & $0.19 \pm 0.08$ & $0.25 \pm 0.07$ & $0.28 \pm 0.1$ \\
\% CVO & $2.6 \pm 0.2$ & $2.9 \pm 0.85$ & $3.1 \pm 0.68$ \\
Gut & & & \\
Flow & $55 \pm 16$ & $43 \pm 14$ & $41 \pm 10 \dagger$ \\
Resistance & $0.71 \pm 0.18$ & $1.0 \pm 0.46$ & $2.0 \pm 3$ \\
\% CVO & $5.4 \pm 2.4$ & $4.8 \pm 2.1$ & $5.4 \pm 3$ \\
Periphery & & & \\
Flow & $23 \pm 10$ & $18 \pm 8$ & $15 \pm 7$ \\
Resistance & $1.7 \pm 0.9$ & $2.3 \pm 1.2$ & $3.0 \pm 1.6 \dagger$ \\
\% CVO & $40 \pm 1.2$ & $40 \pm 1.2$ & $40 \pm 1.2$ \\
Brain & & & \\
Flow & $117 \pm 43$ & $123 \pm 35$ & $109 \pm 47$ \\
Resistance & $0.31 \pm 0.06$ & $0.30 \pm 0.08$ & $0.36 \pm 0.12$ \\
\% CVO & $2.8 \pm 1$ & $3.5 \pm 1.4$ & $3.7 \pm 1$ \\
Myocardium & & & $166 \pm 31$ \\
Flow & $193 \pm 71$ & $207 \pm 78$ & $3.0 \pm 0.6$ \\
Resistance & $0.17 \pm 0.03$ & $0.19 \pm 0.05$ & $0.22 \pm 0.05$ \\
\% CVO & $2.6 \pm 1$ & $3.0 \pm 1.5$ & \\
\hline
\end{tabular}

* Flows are expressed as $\mathrm{ml} / \mathrm{min} / 100 \mathrm{~g}$ wet tissue wt (mean $\pm \mathrm{SD}$ ). Resistances are calculated as the quotient of the arteriovenous pressure difference and blood flow and are expressed in units of $\mathrm{mm} \mathrm{Hg} / \mathrm{ml} / \mathrm{min} /$ kg. \% CVO is calculated as flow/combined ventricular output $\times 100$.

$\dagger p<0.05 ; n=9$.

from $127 \pm 13$ to $565 \mathrm{pg} / \mathrm{ml}$ at the end of hypoxia and to 1490 $\mathrm{pg} / \mathrm{ml}$ during the recovery period (8). Thus, the low-dose infusion of ANP used in these studies increased fetal plasma ANP concentrations to levels similar to those observed when the fetus was mildly volume expanded, whereas the high-dose infusion of ANP increased plasma concentrations to ranges observed during marked decreases in arterial oxygen content. The results from these studies demonstrate that the plasma ANP concentration achieved with the low-dose ANP infusion was associated with minimal and statistically insignificant changes in cardiovascular or renal function. However, the larger plasma ANP concentration achieved with the high-dose ANP infusion was associated with significant changes in combined ventricular output and umbilical-placental blood flow. This implies that acutely, very high plasma ANP concentrations are required to effect cardiovascular changes in the fetus.

Infusion of the high dose of ANP decreased umbilical-placental blood flow by $45 \%$ and combined ventricular output by $33 \%$, but did not significantly change blood flow to other organs, mean arterial blood pressure, or heart rate. The decrease in combined ventricular output is in agreement with findings in adults, in which ANP has been shown to decrease mean circulatory filling pressure (14), venous return, and cardiac output (3). The mechanisms responsible for the decrease in umbilical-placental blood flow and combined ventricular output are not known. Decreased fetal circulating blood volume is a possible explanation. We have shown that increases in plasma ANP concentrations within the physiologic range increased hematocrit, $\mathrm{Hb}$, and plasma protein concentrations by a degree consistent with a $5 \%$ decrease in fetal blood volume. In addition, Brace and Cheung (10) have shown that injection of large quantities of ANP decreases fetal blood 

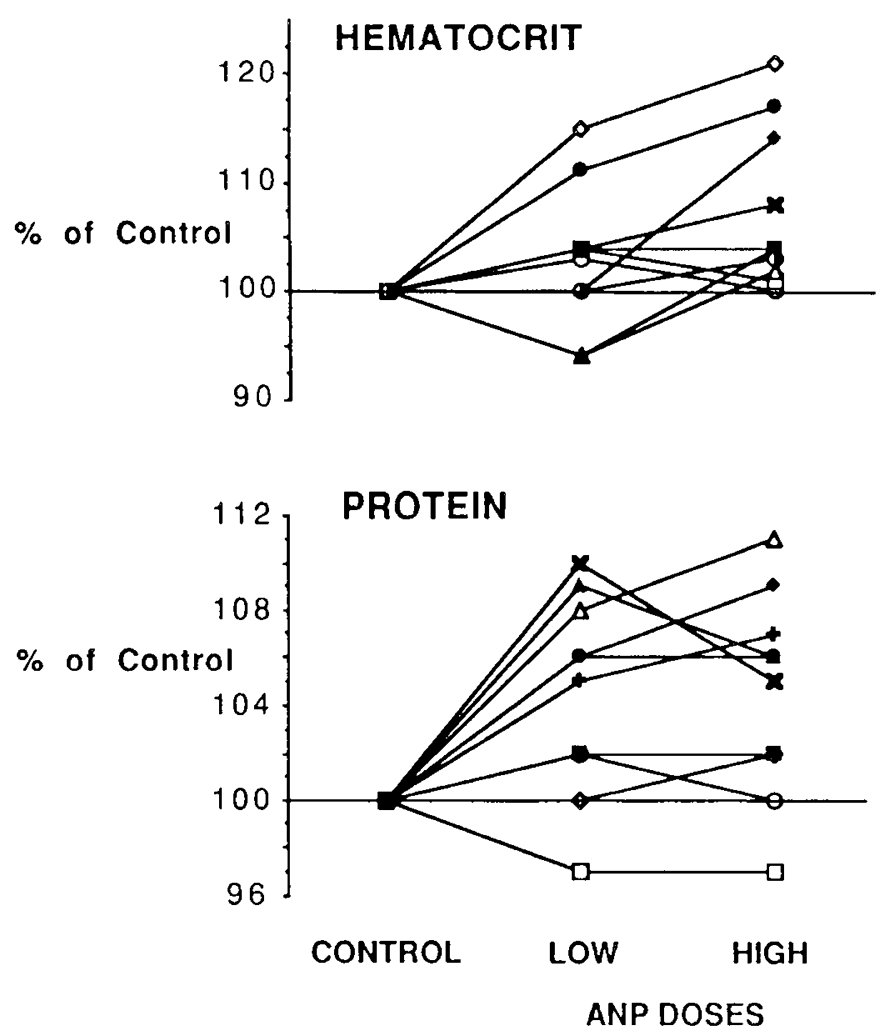

Fig. 1. Effect of ANP on hematocrit and plasma protein concentrations in individual animals. Data are expressed as percent of control.

Table 4. Renal effects of atrial natriuretic peptide infusion in the fetal lamb (mean $\pm S D$ )

\begin{tabular}{|c|c|c|c|}
\hline & Control & $\begin{array}{l}\text { Low ANP } \\
\text { dose }\end{array}$ & $\begin{array}{l}\text { High ANP } \\
\text { dose }\end{array}$ \\
\hline $\mathrm{GFR}(\mathrm{ml} / \mathrm{min})$ & $3.5 \pm 0.9$ & $4.1 \pm 1.1$ & $4.4 \pm 1.5$ \\
\hline $\begin{array}{l}\text { Urine flow rate }(\mathrm{ml} / \\
\text { min) }\end{array}$ & $0.54 \pm 0.2$ & $0.51 \pm 0.2$ & $0.48 \pm 0.2$ \\
\hline $\begin{array}{l}\text { Sodium filtration }(\mu \mathrm{Eq} / \\
\min )\end{array}$ & $486.1 \pm 121.4$ & $570.3 \pm 166.3$ & $620.6 \pm 209.9$ \\
\hline $\begin{array}{l}\text { Sodium excretion }(\mu \mathrm{Eq} / \\
\min )\end{array}$ & $16.8 \pm 7.2$ & $18.1 \pm 7.3$ & $24.7 \pm 10.8$ \\
\hline Sodium reabsorbed $(\%)$ & $96.0 \pm 0.01$ & $96.0 \pm 0.01$ & $95.0 \pm 0.02$ \\
\hline
\end{tabular}

volume. This apparent decrease in blood volume may have contributed to the observed decrease in umbilical-placental blood flow and combined ventricular output, but the effect would be small $(15,16)$. The mechanisms by which ANP might decrease fetal blood volume are unclear. In vitro studies by Huxley et al. (17) have shown that ANP increases hydraulic conductivity, and in vivo studies by Almeida et al. (18) showed that ANP increases fluid filtration across nonrenal capillary beds. Taken collectively, these data suggest that ANP may reduce intravascular volume by increasing net fluid filtration out of the vascular compartment, but whether ANP has these actions in the fetus is unknown (19). The decrease in plasma volume could be due to a redistribution of volume between the fetus and either its interstitial space or its amniotic fluid cavity. The primary effect of ANP may have been to decrease plasma volume, and the other observed responses (i.e. the decrease in combined ventricular output and umbilicalplacental blood flow and the increase in total peripheral vascular resistance and umbilical-placental vascular resistance) may be secondary to the decrease in blood volume.

It is possible that changes observed with ANP infusion were not mediated by a direct action but instead involved participation of other endocrine mechanisms. In vivo studies by Breuhaus et al. (3) demonstrated that ANP infusion decreases cardiac output and increases total peripheral vascular resistance. Ganglionic blockade abolished the increase in total peripheral vascular resistance, suggesting that the increase was mediated by a reflex increase in sympathetic outflow to the periphery. It is possible that sympathetic mechanisms may have mediated the increase in peripheral vascular resistance in the fetus. However, because infusions of epinephrine and norepinephrine do not directly alter umbilical-placental vascular resistance (20), some other mechanism(s) may also be involved. Increases in the plasma ANP concentration have been shown to increase plasma renin activity (12). If ANP also increases angiotensin II concentrations, this may be one mechanism contributing to the increase in umbilicalplacental vascular resistance (20). Because the activity of other vasoactive hormones may have been altered by ANP infusion in these studies, the responses we observed were probably a combination of ANP and other hormone effects.

Another possible explanation for the observed decrease in combined ventricular output and umbilical-placental blood flow is the direct effects of ANP on the placenta to increase placental vascular resistance and to decrease umbilical-placental blood flow. Sen (21) as well as Hatjis and Grogan (22) have shown that ANP receptors are present in the placenta, but the physiologic significance of these receptors is unclear.

Although there was a $45 \%$ decrease in umbilical-placental blood flow in response to ANP, there were no observed changes in fetal blood gases, suggesting that oxygen consumption decreased in the fetus.

Unlike Shine et al. (11), we did not observe significant changes in urine volume, GFR, or urinary sodium excretion. The fetuses studied by Shine et al. (12) were younger (103-129 d gestation) and possibly weighed less than our fetuses. This would make the highest dose of ANP infused by Shine et al. (12) $(70 \mathrm{ng} / \mathrm{min})$ somewhat greater than our highest ANP dose $(55 \pm 8 \mathrm{ng} / \mathrm{kg} /$ $\mathrm{min}$ ) and may account for the discrepancy in the renal response. Our renal data are in agreement with results reported by Robillard et al. (12) showing no significant change in urine volume or GFR. However, we did not observe the significant increase in urinary sodium excretion observed by these investigators. It is possible that our highest infused dose of ANP $(55 \pm 8 \mathrm{ng} / \mathrm{kg} /$ min) compared to the highest infused dose of ANP $(100 \mathrm{ng} / \mathrm{kg} /$ min) used by Robillard et al. (12) was not a sufficient stimulus to significantly increase urinary sodium excretion. In addition, the increases in fetal urinary sodium excretion observed by Robillard et al. (12) were much less than the increases in urinary sodium excretion they observed in the newborn or adult animals.

The fetus cannot tolerate, on a long-term basis, a net water transfer between the fetal and maternal plasma except in the amount required for fetal growth (15). When the fetus receives more fluid from the mother than is necessary for growth and development, mechanisms must be invoked to regulate fluid and electrolyte balance. ANP may play a critical role in this process. Increases in plasma ANP concentrations may decrease fetal blood volume and combined ventricular output by increasing the transfer of fluid from the fetal vascular compartment into the interstitial compartment or to the amniotic fluid cavity. However, the $4-5 \%$ decrease in fetal blood volume does not appear to be enough to account for the dramatic fall in combined ventricular output and umbilical-placental blood flow observed in our study, suggesting that some other mechanism may be involved. One may speculate that ANP has a direct negative inotropic effect on the fetal heart, thus causing a decrease in combined ventricular output. Further studies are needed to test this hypothesis. In summary, ANP may play a crucial role in maintaining fluid homeostasis in the fetus through its ability primarily to decrease fetal blood volume, and secondarily to decrease combined ventricular output and umbilical-placental blood flow. 
Acknowledgments. The authors thank Mr. Bruce Payne and Mr. Carl McWatters for their help with the microsphere data analysis and Mr. Paul Sagan for preparing and editing this manuscript. We also thank Dr. Craig Metzler for his expert advice.

\section{REFERENCES}

1. Lang RE, Ruskoaho H, Toth M, Ganten D, Unger T, Dietz R 1987 Mechanisms controlling release of atrial natriuretic peptide. In: Mulrow PJ, Schrier $\mathrm{R}$ (eds) Atrial Hormones and Other Natriuretic Factors. Williams \& Wilkins, Baltimore, pp 19-33

2. Atlas SA, Laragh JH 1987 Physiological actions of atrial natriuretic factor. In: Mulrow PJ, Schrier R (eds) Atrial Hormones and Other Natriuretic Factors. Williams \& Wilkins, Baltimore, pp 53-76

3. Breuhaus BA, Saneii H, Brandt MA, Chimoskey JE 1985 Atriopeptin II lowers cardiac output in conscious sheep. Am J Physiol 249:R776-R780

4. Scheuer DA, Thrasher TN, Quillen EW Jr, Metzler CH, Ramsay DJ 1987 Atrial natriuretic peptide blocks renin response to renal hypotension. Am J Physiol 251:R423-R427

5. Bie P, Wang BC, Leadley RJ Jr, Goetz KL 1988 Hemodynamic and renal effects of low-dose infusions of atrial peptide in awake dogs. Am J Physio 254:R161-R169

6. Metzler C, Ramsay DJ 1989 Atrial peptide potentiates renal responses to volume expansion in conscious dogs. Am J Physiol 256:R284-R289

7. Scott JN, Jennes L 1987 Distribution of atrial natriuretic factor in fetal rat atria and ventricles. Cell Tissue Res 248:479-481

8. Cheung CY. Brace RA 1988 Fetal hypoxia elevates plasma atrial natriuretic factor concentration. Am J Obstet Gynecol 159:1263-1268

9. Ross MG. Ervin MG, Lam RW, Castro L, Leake RD, Fisher DA 1987 Plasma atrial natriuretic peptide response to volume expansion in the ovine fetus. Am J Obstet Gynecol 157:1292-1297
10. Brace RA, Cheung CY 1987 Cardiovascular and fluid responses to atrial natriuretic factor in sheep fetus. Am J Physiol 253:R561-R567

11. Shine P, McDougall JG, Towstoless MK, Wintour EM 1987 Action of atrial natriuretic peptide in the immature ovine kidney. Pediatr Res 22:11-15

12. Robillard J, Nakamura KT, Varille VA, Andresen AA, Matherene GP, Van Orden DE 1988 Ontogeny of renal response to natriuretic peptide in sheep. Am J Physiol 254:F634-F64

13. Heymann MA, Payne BD, Hoffman JIE, Rudolph AM 1977 Blood flow measurements with radionuclide-labeled particles. Prog Cardiovasc Dis 20:55-79

14. Trippodo NC, Cole FE, Frohlich ED, MacPhee AA 1986 Atrial natriuretic peptide decreases circulatory capacitance in areflexic rats. Circ Res 59:291296

15. Faber JJ, Gault CT, Green TJ, Thornburg KL 1973 Fetal blood volume and fetal placental blood flow in lambs. Proc Soc Exp Biol Med 142:340-344

16. Gilbert RD 1980 Control of fetal cardiac output during changes in blood volume. Am J Physiol 238:H80-H86

17. Huxley VH, Tucker VL, Verburg KM, Freeman RH 1987 Increased capillary hydraulic conductivity induced by atrial natriuretic peptide. Circ Res 60:304307

18. Almeida FA, Muneya M, Maack $\Upsilon 1986$ Atrial natriuretic factor increases hematocrit and decreases plasma volume in nephrectomized rats. Life Sci 39:1193-1199

19. Brace RA, Miner LK, Siderowf AD, Cheung CY 1988 Fetal and adult urine flow and ANF responses to vascular volume expansion. Am J Physiol 255:R846-R850

20. Berman W, Goodlin RC, Heyman MA, Rudolph AM 1978 Effects of pharmacologic agents on umbilical blood flow in fetal lambs in utero. Biol Neonate 33:225-235

21. Sen I 1986 Identification and solubilization of atrial natriuretic factor receptors in human placenta. Biochem Biophys Res Commun 135:480-486

22. Hatjis CG, Grogan DM 1988 Atrial natriuretic peptide receptors in sheep cotyledons. Am J Obstet Gynecol 159:1337-1340 